\title{
MANDADOS E SENTENÇAS LIMINARES
}

(Contribuição para a reforma processual)

\author{
Prof. GALENO LACERDA \\ (Catedrático de Direito Judiciário Civil na \\ Universidade Federal do Rio Grande do Sui)
}

\section{Trafamento do assunto no direito brasileiro.}

1. Encontramos a cada passo no direito processual civil brasileiro a autorização legal para o decreto de atos judiciais coercitivos, logo ao início da demanda, através de mandados liminares a benefício do autor, ou requerente.

Até a possibilidade de sentença ao umbral do processo já ocorre em determinados casos, com tendência nítida de ampliação a hipóteses outras.

Um simples perpassar de olhos pelo Código revela-nos, de fato, inúmeras situações desta natureza.

A começar pelos procedimentos especiais, aparece, já de início, o mandado liminar executório nas ações executivas (art. 299), idêntico ao das ações de execução de sentença por quantia certa (art. 918).

Surge, a seguir, o mandado de preceito cominatório, nas ações de igual nome, com possibilidade, até, de execução liminar direta a benefício de ente público (art. 305), ou de caução inicial contra dano infecto (art. 304). Nestas ações, autoriza o Código, ainda, expressamente, a edição imediata da sentença, em caso de desobediência ao preceito, revelia ou confissão (arts. $303, \S 1 .^{\circ}$, e 307, § 1. ${ }^{\circ}$ ).

Nas ações de consignação em pagamento, da mesma forma, a contumácia do réu autoriza também a prolação direta da sentença (art. 317, § 2..$^{\circ}$.

Seguem-se, na ordem estabelecida pelo Código, a apreensão, depósito e até reintegração liminar na posse da coisa, nas ações re'ativas a vendas com reserva de domínio (art. 344 e $\S \S 4 .^{\circ}$ e $6 .^{\circ}$ ). 
Depois, temos a intimação inicial nas ações de adjudicação, para outorga de escritura definitiva, com possibilidade, ainda, de sentença imediata em hipótese de revelia (art. 346 e $\S 10^{\circ}$ ).

Idêntica sentença é autorizada nas ações de despejo (art. 350, e art. $5 .^{\circ}$ e $\S$ único do Decreto-lei n. ${ }^{\circ} 4$, de $7 / 2 / 66$ ), e nas renovatórias (art. 354), facultando-se, agora, no despejo, o julgamento de plano do mérito, embora contestada a ação, se a matéria for só de direito, ou não houver necessidade de prova em audiência (art. 2. ${ }^{\circ}$ do Decreto-lei n. ${ }^{\circ} 890$, de 26/9/69).

Já na ação de depósito, encontramos o mandado liminar de prisão contra o depositário infiel, que não cumprir a ordem de depósito prévio do objeto ou de seu equiva!ente em dinheiro (art. 369).

Chegamos, então, às ações possessórias, com mandado liminar nos interditos de manutenção, reintegração e proibitório (arts. 371 e 378), e, bem assim, com sentença inicial, ocorrida a revelia, não só nestes interditos (arts. 376 e 380), serão que ainda na ação de imissão de posse (art. 382, § único).

Logo após, deparamos o embargo liminar de obra nova (art. 386), e a sentença inicial, em hipótese de acôrdo ou confumácia, na ação de remição de imóvel hipotecado (art. 395), na de venda, locação e administração da coisa comum (art. 406, § $2 .^{\circ}$ ), e na de usucapião (art. 456).

2. Igualmente, em leis especiais reguladoras de outras ações, encontramos a incidência de atos judiciais idênticos.

Assim, no executivo fiscal, o mandado executório prévio e a sentença imediata em revelia (arts. $60^{\circ}$ e 19, IV, do Decreto-Lei n. ${ }^{\circ}$ 960, de 17/11/38).

No mandado de segurança, a importantíssima liminar suspensiva (art. $7 .^{\circ}$, da Lei n. ${ }^{\circ} 1.533$, de $31 / 12 / 51$ ).

Nas desapropriações, a imissão prévia na posse (art. 15 do Decreto-'ei n..$^{\circ} 3.365$, de 21/6/41; art. 19, § 2., b, do Estatuto da Terra), o mesmo ocorrendo na desapropriação de bens destinados ao abastecimento e ao serviço público, onde se frise que a imissão será realizada antes da citação (art. $4 .^{\circ}$ do Decreto-lei n. ${ }^{\circ} 422$, de 20/1/69), e nas desapropriações de áreas prioritárias para a reforma agrária, onde se ordena, até, a transcrição liminar do mandado de imissão no Registro de Imóveis, para efeitos de transmissão de domínio (arts. 6. ${ }^{\circ}$ e $7 .^{\circ}$ do Decreto-lei n. ${ }^{\circ} 554$, de 25/4/69). 
Na ação executiva para cobrança de duplicata, também nos defrontamos com a sentença de plano, em caso de revelia (art. 15, § 5. ${ }^{\circ}$, da Lei n. ${ }^{\circ}$ 5.474, de 18/7/68).

$\mathrm{Na}$ excussão da cédula rural pignoratícia, surge o mandado liminar de depósito ou sequestro do bem móvel ou semovente, seguido do de prisão preventiva do devedor (art. 23 e parágrafos da Lei n. ${ }^{\circ} 492$, de 30/8/37).

Na execução de cédula hipotecária, a imissão liminar na posse do imóvel, em favor do arrematante (art. 37, § 2. ${ }^{\circ}$, do Decreto-'ei 70, de $21 / 11 / 66)$.

$\mathrm{Na}$ da cédula industrial, a penhora ou sequestro iniciais (art. 41, $\S 2 .^{\circ}$, do Decreto-lei n. ${ }^{\circ} 413$, de 9/1/69).

Na alienação fiduciária, a busca e apreensão liminares do bem objeto do contrato (art. $3 .^{\circ}$ e $\S 1 .^{\circ}$ do Decreto-lei n. ${ }^{\circ} 911$, de 1/10/69.

Nas ações de alimentos e outras onde êstes couberem, a decretação provisória e inicial dos mesmos (arts. 4 e 13 da Lei n. ${ }^{\circ}$ 5.478 , de $25 / 7 / 68)$.

3. Mas, se tais medidas cabem em ações principais, com mais razão se justifificam nos procedimentos onde atua a função cautelar da jurisdição.

Eis por que autoriza o Código, de modo geral, a concessão de liminares nas medidas preventivas inaudiente altera parte (art. 683).

Da mesma forma, haveremos de encontrar mandados iniciais imperativos naqueles processos, cautelares ou não, que poderíamos denominar incidentes, ou derivados.

Em tais hipóteses, o mandado assume o caráter suspensivo do processo ou processos principais.

Deparamo-'o nos embargos de terceiro (art. 708, § 1.०), no atentado (art. 712), no incidente de falsidade (art. 719), e de modo eventual na habilitação incidente (art. 753).

Idêntica providência se impõe nos conflitos de jurisdição (art. 806, I), e poderá ocorrer também na reclamação perante o Supremo Tribunal Federal (art. 163 do respectivo Regimento), e nas correições parciais reguladas em leis de organização judiciária e regimentos dos Tribunais.

Recente lei outorgou efeito suspensivo da execução à própria ação rescisória, quando movida a benefício da Fazenda Pública (Decreto-lei n. ${ }^{\circ} 1.030$, de $\left.21 / 10 / 69\right)$. 
Cumpre, ainda, para encerrar esta longa relação, meramente enunciativa, das medidas liminares de coerção existentes no processo civil brasileiro, mencionar aquelas que ocorrem, a tôda evidência, nos três tipos de ação executória de sentença, disciplinados pelo Código. Além da providência inicial na execução por quantia certa (art. 918), já referida, impõe-se lembrar, aqui, os mandados pertinentes às execuções por coisa certa ou em espécie (arts. 992 e 993), e às relacionadas com as obrigações de fazer ou não fazer (art. 998).

4. Como se tem comportado a doutrina nacional ante êstes importantíssimos atos judiciais de autoridade, emanados logo ao umbral dos processos, atos cuja ocorrência cada vez mais se apresente nas leis modernas?

Acaso terá surgido, ao menos, alguma indagação sistemática a respeito do assunto, ou, ao contrário, os comentários se quedam no casuísmo das hipóteses legais?

Haverá, mesmo, algum traço comum que justifique a consideração, em sistema unitário, de procedimentos aparentemente tão dispares, como os peculiares às ações cominatórias, aos executivos de tôda espécie, aos interditos possessórios, ao mandado de segurança, às medidas cautelares, enfim, ao imenso ro! de processos acima enunciados? A própria especialização com que são considerados no Código e em leis extravagantes não estará, acaso, a indicar diversidade inconciliável e irredutível a qualquer aproximação conceitual?

$\mathrm{Na}$ verdade, nossos autores têm-se omitido à análise do assunto. Os vários tipos de procedimento estudam-se separados em monografias e comentários, e, em regra, nos próprios currículos de ensino, como se nada os unisse, quais excrescências exóticas, cada uma com sua forma individual, vária e excêntrica, a perturbar a harmonia e unidade de sistema do procedimento ordinário.

Propomo-nos demonstrar que, ao contrário dessa perspectiva individualizadora e estanque, tais procedimentos se vinculam, pela origem e finalidade, a outro sistema processual, a outro modo instrumenta!', igualmente orgânico e válido, de fazer-se justiça em concreto.

A unidade de origem revela-se flagrante e surpreendente, a partir de um estudo atento e profundo dos interditos romanos.

\section{Os interditos romanos}

5. Quando se fala em interditos processuais acode logo a idéia dos remédios possessórios, donde a tendência dos menos avisados a pensar que os interditos do direito romano reduziam-se apenas à tutela da posse. 
Nada mais falso.

No direito clássico, destinavam-se êles a todo tipo de proteção material. Existiam em grande número. LENEL e RICCOBONO anotam quarenta e sete ${ }^{1}$ ). Outros falam em cêrca de sessenta, referindo-se apenas às espécies típicas $\left({ }^{2}\right)$, número que poderia aumentar de maneira indeterminada, porque era livre a criação de interditos úteis ou ad-hoc pelo pretor $\left({ }^{3}\right)$.

Natural que para matéria tão vária inúmeras sejam as classificações propostas. Limitar-nos-emos aqui a referir as mais importantes.

Segundo a fina!idade do mandado emitido pelo pretor, os interditos poderiam ser proibitórios, exibitórios ou restitutórios. ${ }_{4}$ )

Os primeiros, denominados negativos, impunham um veto, isto é, um não-fazer, a determinada conduta.

Os outros, positivos, e por isto chamados mais pròpriamente decretos, consistiam numa ordem comissiva, num comando para exibir ou restituir algo: exhibeas, restituas.

Quanto ao objeto, GANDOLFI os dispõe em três grandes categorias $\left(^{5}\right)$.

Na primeira, arrolam-se aquêles que regulam relações de direito sucessório. São os interditos quorum bonorum, quod legatorum, quam hereditatem, de tabulis exhibendis, êste destinado à exibição de testamento, e outros.

A seguir, classificam-se os que visam tutelar relações de senhorio e gôzo de coisas públicas e privadas, ou relações de garantia. Consideram-se aqui os interditos de proteção a lugares sagrados e ao direito de sepultar os mortos; ao livre uso de lugares e vias púb!icas, inclusive de águas e rios, com a consequente proibição ou demolição de obras que o impeçam; os destinados à tutela da posse, do usufruto, à causação de dano infecto, às servidões de passagem, de água ou de aqueduto, à nunciação de obra nova, e, até, à proteção de bens em relações de locação (interdictum de migrando e Salvianum), ou contra a alienação em fraude ao credor (interdictum fraudatorium).

Finalmente, num terceiro grupo, situam-se os que visam a tute-

(1) RICCOBONO, Interdicta, in Novissimo Digesto Italiano, vol. VIII, p. 794.

(2) GANDOLFI, Contributo allo Studio del Processo Interditale Romano, Giuffrè, 1955, p. 2.

(3) BISCARDI, La Protezione Interditale nel Processo Romano, Cedam, 1938, ps .34 e 131; GANDOLFI, op. cit., p. 95).

(4) SCIALOJA, Procedimiento Civil Romano, Buenos Aires, 1954, p. 315.

(5) Ob. cit., ps. 139 e ss. 
la da liberdade pessoal, especialmente no que diz respeito às relações de família. São os interditos de homine libero exhibendo, de liberis exhibendis item ducendis, de libero exhibendo, de uxore exhibenda, etc.

6. Consistiam os interditos numa ordem emanada diretamente do magistrado romano, a pedido de uma pessoa privada contra outra, na qual se impõe, a esta, um certo comportamento $\left(^{6}\right)$.

Apesar de o lifígio surgir entre particulares, através dêle tutelava-se também o interêsse público, na medida em que seu objeto consistia no uso de bens públicos, ou em situações de fato protegidas pela ordem social ${ }^{(7)}$.

Acontece que as coisas públicas, nas origens mais remotas, eram consideradas comunhão de todos, e, assim, o interdito protegia um interêsse privado do qual todos, indiretamente, participam, sendo que, até, em determinadas hipóteses, o interêsse era, na verdade, geral, tratando-se então, de autênticos interditos populares, onde a iniciativa do interdicente assumia a mesma característica da do autor na ação pupular ${ }^{(8)}$.

Costumam os romanistas vincular o nascimento da tute'a interdital à necessidade de proteger a posse nas concessões do ager publicus, segundo a concepção de NIEBUHR e SAVIGNY $\left({ }^{9}\right)$. As terras ocupadas ou conquistadas, cujo domínio permanecia público, eram concedidas, em frações individuais de posse (fundus) aos pais de família, ou simplesmente abandonadas aos particulares. Os primeiros litígios haveriam de assumir, pois, caráter possessório. Adverte, porém, GANDOLFI que, apesar de não se poder cogitar, então, de propriedade privada da terra, com as peculiaridades do direito de domínio mais tarde definido, tratava-se, na verdade, de um autêntico direito de senhorio. $\left({ }^{10}\right)$

Parece evidente, pois, que nesta época mais recuada, surgido - litígio, procurasse o interessado a autoridade pública do pretor para reclamar contra a conduta do adversário. Eis aí o interdito, a

(6) RICCOBONO, ob. cit.

(7) GANDOLF, ob. cit., p. 69.

(8) GANDOLFI, ob. cit., ps. 151 a 153; SAVIGNY, Sistema del Diritto Romano Attuale, trad. SCIALOJA, 1888, II $\S 73$, p. 141.

(9) SAVIGNY, Traité de la Possession en Droit Romain, Bruxelas, 1879, § 12a, p. 179; ZIMMERN, Traité des Actions ou Théorie de la Procédure Privée chez les Romais, Paris ,1843, p. 219; PACCHIONI, Corso di Diritto Romano, II, § 9, p. 210; MAYNZ,Cours de Droit Romain, Bruxelas, 1876, I, $\S 88$, p. 664; BISCARDI, op. cit., p. 117.

(10) Ob. cit., ps. 154 a 156. 
desencadear a intervenção do magistrado, mediante procedimento baseado no imperium, fonte do edito pretoriano $\left({ }^{11}\right)$.

Os estudos mais recentes convêm em que essa forma simples e direta de tutela jurídica foi contemporânea senão que anterior ao período das legis actiones, cujo formalismo complexo e sofisticado denunciaria estágio posterior de evolução social. Não têm razão, assim, os autores que explicam o aparecimento dos interditos pela necessidade de suprir-se a falta de ações do ius civile, visto como aquêles teriam sido mais antigos do que estas $\left({ }^{12}\right)$.

7. Exatamente porque se dispunham a tutelar também coisas pú-

blicas, proclamam os romanistas, em coro quase unânime, a natureza administrativa do interdito $\left({ }^{13}\right)$.

Contra esta concepção, levanta-se GANDOLFI, em trabalho notável pela profundidade, rigor lógico e coerência de análise das font'es, a sustentar o caráter jurisdicional dêsse remédio jurídico.

A razão fundamental é que o decreto do pretor incide sôbre a !ide concreta, com o objetivo de resolvê-la em definitivo, mediante um ato vinculativo de autoridade, de imperium, que constituia autêntico juízo de mérito $\left({ }^{14}\right)$.

Demonstra GANDOLFI que, ao contrário das opiniões correntes que reduziam o interdito a um procedimento sumário, quase que a uma formalidade perante o pretor, com o objetivo de obter-se um mandado contra o adversário, ordem que êste poderia livremente descumprir para optar pela ação indenizatória posterior, a actio ex-interdicto, trata-se, na verdade, de um verdadeiro processo com cognição plena do magistrado, a desenvolver-se, ao contrário das ações, apenas in jure, sem intervenção dos juízes privados do processo formulário.

A cognitio do interdito podia exigir, até, mais de uma audiência perante o pretor $\left({ }^{15}\right)$, admitindo-se, inclusive, a oposição de exceções pelo demandado $\left({ }^{16}\right)$, de tal modo que a decisão final poderia assumir uma dentre três soluções: ou o pretor reconhecia fundada a exceção,

(11) GANDOLFI, ob. cit., ps. 22, 54, 55, 98 e 128.

(12) GANDOLFI, ob. cit., p. 121; BISCARDI, ob. cit., ps. 103 e 105.

(13) BONFANTE, Histoire du Droit Romain, Sirey, 1928, I, p. 522; COSTA, Storial del Diritło Romano Privato, 2.a ed., 1925, p. 294, e Profilo Storico del Processo Civile Romano, Roma, 1918, p. 105; RICCOBONO, ob. cit., loc. cit.; BETTI, Istituzioni di Diritto Romano, Cedam, 1947, § 100, p. 339; SCIALOJA, ob. cit., p. 312; BISCARDI, ob. cit., ps. 31, 56, 57, 76, 82, 94 e 96; CORREIA-SCIASCIA, Manual de Direito Romano Saraiva, 1949, I, § 49, p. 94.

(14) GANDOLFI, ob. cit., ps. 17, 21 a 25, 62, 64, 79, 81, 96, 97, 126 e 149.

(15) GANDOLFI, ob. cit., p. 46.

(16) Ob. cit., ps. 72 e 75. 
e repelia o pedido; ou, ao contrário, concedia o decreto, porque infundada ou inexistente a exceptio; ou, finalmente, considerando a equidade da objeção, mas não podendo, pela complexidade do assunto, a demandar prova ulterior, ou pe'́o próprio acúmulo de serviço, decidir o litígio, pronunciava, então, um interdito condicionado à exceção, remetendo, assim, implìcitamente, as partes à actio posterior $\left.{ }^{17}\right)$.

Demonstra GANDOLFI, com vantagem, ainda em contrário à opinião dominante, que, no princípio, a decisão interdital era sempre imperativa e incondicionada $\left({ }^{18}\right)$. O decreto condicionado ou hipotético, a findar com a cláusula ou a ressalva nisi ("a não ser que", "exceto"), só surgiu depois, com o aumento e complexidade dos litígios, sem eliminar, contudo, as outras hipóteses de solução definitiva in jure ${ }^{(19)}$.

8. A permanência e ampliação dos interditos durante o período c'ássico do procedimento formulário revela, pois, que Roma conheceu, na verdade, dois grandes sistemas processuais paralelos de tutela jurídica, distintos na forma e diversos nos meios, e, em certo sentido, no próprio objetivo, embora tendentes, ambos, à solução definitiva da lide.

Esta, a grande, a enorme contribuição dos estudos romanísticos mais recentes, contribuição que nos obriga, mesmo, como nos propomos sugerir, a uma profunda revisão sistemática do direito processual moderno.

Com efeito, enquanto o interdito consistia numa ordem para as partes, com solução concreta do litígio e, portanto, podia ser decretado até em revelia, não admitindo representação, o mandado formulário, na actio, se traduzia numa ordem para o juiz privado, com declaração meramente abstrata do direito em tese, a exigir o comparecimento de ambas as partes, in jure, na litiscontestatio, admitida a representação ampla. No primeiro caso, cognição completa da lide, in jure, pelo pretor; no segundo, a cognição dos fatos in judicio, confiada ao árbitro particular. Daí, a natureza eminentemente publicísta do mandado interdital, em contraposição com o caráter privado da sentença arbitral. ${ }^{(20)}$.

Mas, consegue GANDOLFI, através de análise estupenda, mostrar, rambém, que êstes sistemas diversos de procedimento consti-

(17) GANDOLFI, ob. cit.; ps. 75 e 76.

(18) Ob. cit., ps. 37, 70, 72 e 90.

(19) Ob. cit., ps. 75 e 80.

(20) GANDOLFI, ob. cit., ps. 34, 50, 56, 57, 66, 69 e 84 . 
tuem a projeção processual de uma distinção básica do próprio direito material romano.

Com efeito, a simples enumeração dos interditos segundo o seu objeto, acima referida, indica que, em todos os casos, se tratava da tutela de direitos absolutos, vinculados às resmancipi. "Esta distinção fundamental - ensinam CORREIA e SCIASCIA - é a mais antiga e funda-se na importância das coisas para a sociedade romana das épocas primitivas. São res mancipi os imóveis situados no solo itálico, os escravos, os animais de tiro e carga, as servidões rústicas mais antigas, iłer, actus, via e a servidão de aqueduto" $\left({ }^{21}\right)$.

Ou, na lição admirável de GANDOLFI, "as relações tuteladas pelos interditos constituiam originàriamente o mancipium do pater-familias, isto é, o poder sôbre os fundos e sôbre as casas, sôbre escravos, sôbre o exercício das várias servidões, sôbre o uso dos bens públicos, cabível a todo cidadão, sobre os filii-familias, sobre bens relativos à sucessão mortis-causa. E esta consideração nos leva a atribuir o início da referida tutela, na forma autoritativa e inquisitória do processo interdital, a um estádio arcaico da vida da comunidade jurídica romana, onde a economia, prevalentemente agrícola, se reduzia à organização de fazendas de base familiar. E é, de outro lado, compreensível também esta tutela sob o aspecto constitucional, porque conexa com a missão de vigilância e intervenção do pretor imperium - destinada a salvaguardar a ordem e a economia da civitas" $\left.^{\prime \prime 2}\right)$.

Eis por que as relações jurídicas mais importantes, pertinentes aos direitos absolutos, eram amparadas pelos interditos, emanados diretamente do poder de imperium do magistrado, ao passo que aquelas meramente obrigacionais conduziam as partes desavindas à actio, com juízo privado, de conteúdo indenizatório.

Ou, segundo GANDOLFI, enquanto a actio consistia no direito ao judicium, com condenação pecuniária, o interdictum era o direito ao decreto, com execução específica a determinado comportamento jurídico $\left({ }^{23}\right)$.

Nos interditos absolutos, incondicionados, a execução coacta poderia cumprir-se, até, manu militari, por exemplo, para demolição de uma obra danosa à utilização das coisas públicas ou privadas protegidas pelo interdito $\left({ }^{24}\right)$.

(21) Ob. cit., I, p. 41.

(22) Ob. cit., p. 142.

(23) Ob. cit., p. 148.

(24) GANDOLFI, ob. cit., ps. 101 e 102. 
Apenas nas hipóteses de se tornar impossível a execução específica, ou de se tratar de interdito condicionado, isto é, com possibilidade de recusa e defesa, é que poderia suceder a ação posterior de ressarcimento, a actio ex-interdicto, onde, se procedente, seriam avaliadas as perdas e danos, oriundos da desobediência ao mandado pretório, com consequente condenação em quantia certa $\left({ }^{25}\right)$.

Ao contrário, portanto, do que sustenta a maioria dos romanistas, baseada em interpretação equivocada do testo de GAIO, afirma GANDOLFI o caráter secundário e supletório do procedimento arbitral posterior, objeto da referida actio. $\left({ }^{26}\right)$

9. De tudo quanto se expôs, ressalta à evidência a magnífica lição do direito romano. Legou-nos, na verdade, a sabedoria de suas instituições dois sistemas autônomos de processo civil, um, voltado à obtenção de mandado inquisitório, por vêzes liminar, concedido mesmo sem a presença da parte contrária, mediante cognição sumária das afirmações do autor, aceitas como verazes, ante a revelia do demandado e se conformes com o edito; outro, destinado à solução de um contraditório manifestado desde o início, com a presença obrigatória das partes, desprovido, portanto, de mandado concreto e relegada a causa à cognição privada.

Esste dualismo haveria de desaparecer, apenas, com a publicização total da actio, ocorrida com a extinção do processo formulário no Baixo Império.

Então, os interditos passaram a denominar-se também "ações", porque todo o procedimento passou a correr perante o pretor, eliminada a fase in judicio, particular.

Veremos porém, que a lição fecunda da dualidade processual romana, haveria de ressurgir, evoluída, na Idade Média e na Renascença, diversa em aspectos acidentais peculiares às necessidades dos tempos novos, contudo, idêntica na revelação de que, no fundo, há dois modelos processuais diversos para a obra de realização individual da justiça.

\section{A evolução do processo interdital no direito canônino, no direito comum e no anglo-saxão.}

10. Informa SOLMI que o direito canônico sentiu cedo a necessidade de adotar um processo abreviado, para obviar, em casos de urgência, as formalidades intermináveis do processo comum. "O

(25) GANDOLFI, ob. cit., ps. 110, 111 e 113.

(26) Ob. cit., p. 114. 
nôvo procedimento, que foi empregado rápida e largamente no campo do processo civil, dizia-se feito summarie, simpliciter, de plano, sine strepiłu et figura iudicii, e não tardou a ser acolhido pelo direito temporal. $\left({ }^{27}\right)$.

Claro está que o modêlo haveria de ser o interdito romano, não evidentemente o dos interditos possessórios que vigoraram na fase final dos judicia extraordinária, assimilados ao procedimento comum das ações, senão que o vigorante na época clássica.

Aconteceu, então, um estranho fenômeno de transferência, de ampliação de conceitos de direito material, com a finalidade exclusiva de obter-se a presteza útil do remédio processual específico.

Como possivelmente, mal se conhecesse, na época, a exiensăo amplíssima de que gozaram os interditos nas recuadas origens do direito romano, e como o direito justinianeu, bem mais próximo no tempo e recém-descoberto no Ocidente pela obra dos glosadores, só recordara dos antigos interditos as ações possessórias (note-se que as Institutas de GAIO só foram descobertas em 1816), aconteceu o curioso equívoco de que a necessidade processual de um remédio sumário fez com que se violentasse e ampliasse o conceito romano de posse, em busca, na verdade, da rapidez do interdito.

Apareceu, então, no século 13, em Itália, Espanha, França e Alemanha, o chamado possessorium summarium ou summarissimum, justificado por SAVIGNY pela" "necessidade absoluta de uma decisão imediata, embora provisória, contra a violência, acima de qualquer outra consideração, mesmo sôbre a de uma convicção perfeita e um conhecimento completo dos fatos" $\left({ }^{28}\right)$.

E ocorreu, em razão disto, a começar pelo direito canônico, a ampliação do conceito de posse aos direitos pessoais, primeiro sôbre os benefícios ligados à jurisdição territorial, direito ao cargo, insígnias, honrarias, privilégios, dízimos, e depois aos direitos de família e, até aos obrigacionais $\left({ }^{29}\right)$.

11. Na Alemanha, êsses interditos, ou summarissima possessoria, passaram a denominar-se inhibitiones, e iniciavam-se com um mandatum, isto é, com uma ordem judicial de tutela do interesse reclamado, expedida mesmo sem citação do réu. $\left({ }^{30}\right)$.

(27) SOLMI, Contributi alla Storia del Diritto Comune, Roma, 1937, p. 206.

(28) Traité de la Possession, cit., § 51, ps. 509 a 511.

(29) SAVIGNY, ob. cit., § 49, ps. 492 e ss; notas de FADDA, BENSA e BONFANTE às Pandectas de WINDSCHEID, 1926, V, ps. 621 e ss.

(30) STRYKIO e STRUVIO, apud ALMEIDA E SOUSA, Açöes Sumárias, I, § 507. 
Segundo informação de HEINECIUS, tais remédios tornaram-se frequentíssimos, e os respectivos mandados iniciais podiam ser expedidos com ou sem cláusula justificativa $\left.{ }^{(31}\right)$.

Esta peculiaridade representa mais uma prova evidente de analogia com os antigos interditos romanos, já notada, aliás, por SAVIGNY ( $\left.{ }^{32}\right)$. Os mandados sem cláusula correspondiam aos interditos absolutos, incondicionados, que não admitiam defesa. Os mandados com cláusula justificativa, ao contrário, equivaliam aos interditos condicionados, hipotéticos, expedidos na hipótese de verazes as afirmações do autor, mas admitindo defesa do réu, cujo comparecimento transformava o preceito em simples citação $\left({ }^{33}\right)$

12. O que há de notável, porém, nas inhibitiones germânicas, foi sua extensão à tutela da relações de direito público, de acôrdo aliás, com a maior sensibilidade dos povos germânicos do que o romano, para êste tipo de vinculações jurídicas.

"O Direito público subjetivo do particular, o direito do administrado contra a administração, uti singulis e não uticivis - escrevemos noutro trabalho $\left({ }^{34}\right)$ - permaneceu confuso e indeterminado no direito romano."

Devemos, sem dúvida, aos povos germânicos "o reconhecimento mais consciente do direito público subjetivo e de sua garantia jurisdicional". Ao contrário da irresponsabilidade funcional dos agentes públicos, que o direito romano admitia como regra, o conceito germânico submetia os órgãos do Estado, mesmo o mais elevado, o rei, ao direito nacional, à lex terrae. $O$ indivíduo lesado, pelo rei ou por outro órgão, em pretensão subjetiva tutelada pela lex terrae, podia postular os seus direitos, primeiro perante a assembléia do povo, depois perante o colégio dos homens-bons ou dos jurados, único tribunal capaz de definir a lei nacional e sancioná-la $\left.{ }^{(35}\right)$.

"Eis por que o primitivo Estado germânico é um Justizestaat, Estado de justiça, anterior ao Polizestaat, Estado-polícia, gerado pelo absolutismo real.

"Compreende-se e justifica-se, diante disto, a ufania de HÄBERLIN ao exclamar, em 1797, referindo-se ao Tribunal Cameral do Império (Reicheskammergericht), fundado em 1495: "É uma felici-

(31) Apud ALMEIDA E SOUSA, ob. loc. cits.

(32) Ob. cit., § 34, p. 363.

(33) CAETANO GOMES, apud MOACYR AMARAL SANTOS, Açōes Cominatórias no Direito Brasileiro, I, ps. 85 e 86.

(34) Remédios Processuais da Administração e contra a Administração, in Revista de Direito Processual Civil, 20 v., p. 24. 
dade que nós, alemães, possamos mover processos que são revo. luções! Enquanto isto nos for lícito, e em consequência da reparação que nossas demandas podem assegurar-nos, estaremos garantidos contra as verdadeiras revoluções violentas" $\left({ }^{36}\right)$.

"O maravilhoso paradoxo da revolução pacífica através do judiciário nada mais era, na verdade, do que a afirmação no direito publico, realizada com singular eficiência pelo Tribunal Cameral do Reich, da vocação pioneira e permanente do processo de desbravador do direito, agora nos domínios até então quase inviolados do "ius publicum".

"A tal ponto chegou a afinação do instrumento processual, no antigo Justizestaat do Reich imperial, no sentido da proteção dos direitos subjetivos públicos do indivíduo, que vamos encontrar, aí, nessa época recuada, o antecedente claro e manifesto de nosso tão justamente exaltado mandado de segurança. "Nos casos em que se tratasse de atos de govêrno nullo modo justificabilia ou se ameaçasse um damnum irreparabile, os súditos tinham ação para reclamar dos tribunais um mandatum sine clausula. $O$ pressuposto dêste processo era a lesão de um direito subjetivo, e a teoria e a prática excluíam a distinção entre direito público e direito privado. E por longo tempo a competência, a propósito, do império, foi inconteste, pois que a discussão versava sôbre a extensão dos poderes de polícia dos senhores territoriais, no limitar os direitos dos súditos" ( $\left.{ }^{37}\right)$.

Para êstes casos graves, de tutela do direito subjetivo do particular contra o poder público, portanto, o mandado podia assumir, até a feição radical, absoluta e perentória, de expedir-se sem cláusula justificativa.

Êstes casos COCCEIUS os sintetiza em quatro hipóteses: se o interdicente possui a seu favor direito ou costume velhos; se ocorre a ameaça de dano irreparável; se o ato atacado é contra a utilidade pública, e se, enfim, ocorre o periculum in mora $\left({ }^{38}\right)$.

Notável é assinalar que o periculum in mora, assim amparado pelas inhibitiones germânicas, através do mandado liminar, constitui o fundamento principal das atuais medidas cautelares, no processo civil dos povos cultos $\left({ }^{39}\right)$.

(35) CAMMEO, Commentario delle Leggi sulla Giustizia Ammnistrativa, I, p. 33.

(36) Handbuch des deutschen Staatsrecht, II, 1797, p. 467, apud Walter JELLINEK, Verwaltungsrecht, 3. Aufl., Berlim, 1931.

(37) CAMMEO, ob. cit., p. 34.

(38) Apud ALMEIDA E SOUSA, Inferditos, § 100.

(39) CALAMANDREl, Providencias Cautelares, Buenos Aires, 1945, p. 42. 
13. A mesma sensibilidade para a tutela dos direitos individuais contra o poder público, encontramo-la no direito anglo-saxão, com a adoçã் dos state-writs na Inglaterra, em tudo análogos às inhibitiones germânicas e com idêntica vinculação aos interditos romanos.

Sua origem remonta também ao século 15 , senão antes $\left(4^{\circ}\right)$. Os principais denominam-se mandamus, prohibition, certiorari, habeas corpus e quo warranto $\left.{ }^{41}\right)$.

O mandamus consiste numa ordem dirigida a autoridade administrativa ou judiciária, para prática de determinado ato. Essa ordem pode ser perentória, ou expedida com a cláusula nisi, idêntica, portanto, à que se encontra na fórmula do interdito romano condicionado, isto é, com ressalva, ou com cláusula justificativa ${ }^{\left({ }^{42}\right)}$.

Prohibition, ao contrário, impõe um veto a determinado comportamento oficial, do mesmo modo como ocorria com os interditos proibitórios romanos, com a diferença de que êstes se voltavam apenas contra o particular.

O certiorari visa anular um processo ou uma decisão judicial, e se inicia com mandado liminar suspensivo $\left({ }^{43}\right)$, podendo concluir com autêntica cassação, à semelhança do que acontecia com a intercessio romana, onde um pretor podia cassar a outorgada actio ou da exceptio por parte do outro $\left.{ }^{(44}\right)$.

O habeas corpus, como é notório, vincula-se diretamente ao interdito de homine libero exhibendo do processo romano ${ }^{45}$ ).

Por fim, o writ quo warranto visa impedir a usurpação de di. reitos, cargos ou privilégios públicos.

Convém mencionar, ainda, no direito anglo-americano, a existência da injunction, remédio judicial de uma parte contra outra, com liminar suspensiva, muito semelhante às medidas preventivas ou incidentes do direito continental ${ }^{(46)}$.

14. O direito medieval, especialmente o estatutário italiano, criou, ainda, dois tipos de mandados com cláusula justificativa, específicos para as relações obrigacionais.

(40) TIXIER, Le Controle Judiciaire de l'Administration Anglaise, Paris, 1954, p. 58.

(41) KUHN, Principes de Droit Anglo-Américain, Paris, 1924, p. 86; FRANQUEVILLE, Le Système Judiciaire de la Grande Bretagne, Paris, 1893, II, ps. 126 e ss.

(42) FRANQUEVILLE, ob. cit., p. 129.

(43) TIXIER, ob. cit., p. 65.

(44) SCIALOJA, ob. cit., ps. 360 e 361.

(45) PONTES DE MIRANDA, História e Prática do Habeas-Corpus, 2.a ed., p. 143.

(46) KUHN, ob. cit., ps. 78 e ss. 


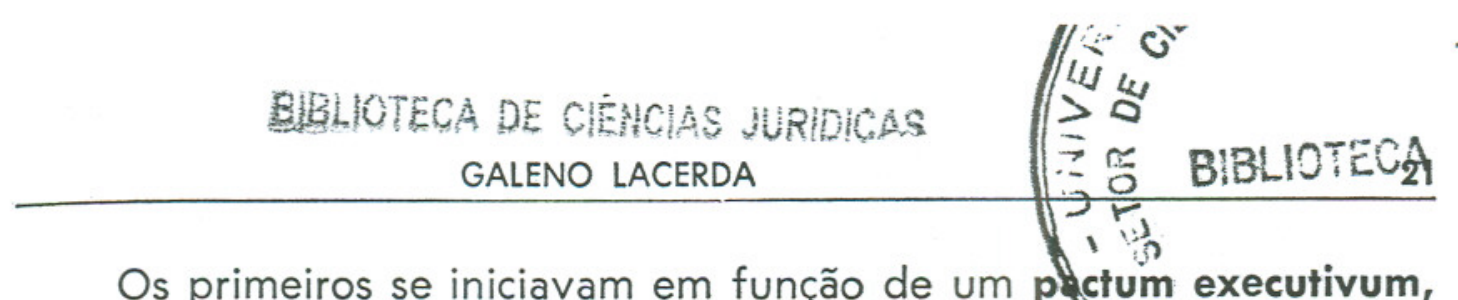

Os primeiros se iniciavam em função de um pactum executivum, constante dos instrumenta guarentigiata, ou confessiogata, no qual as. partes se sujeitavam à execução sem processo prévio, circunstância que reduzia a cognição do juiz e autorizava a expedição de um mandado executório inicial. Eis a fonte das atuais ações executivas, baseadas em título líquido e certo, criação do gênio mercantil das Repúblicas italianas $\left({ }^{47}\right)$.

A segunda contribuição da mesma origem foi o procedimento monitório. Também aqui ocorre a expedição de um mandatum dẽ solvendo, para cobrança de crédito em dinheiro, desacompanhado, porém, de título documental executivo. Trata-se de mandado com cláusula justificativa, isto é, autoriza a oposição do réu $\left({ }^{48}\right)$. Tais mandados são expedidos liminarmente, inaudita altera parte. Se esta não comparece, ou confessa, o preceito se transforma, automàticamente, em sentença executória. Suas características principais são, segundo CALAMANDREI, a celeridade de obtenção do título executório, em procedimento sumário, e a inversão de iniciativa do contraditório, pois que o ônus dêste cabe ao réu, visto como o juiz aceita, em hipótese e sub conditione, as afirmações do autor $\left.{ }^{(49}\right)$.

Contra a opinião dominante, sustenta CALAMANDREI a natureza jurisdicional do mandado monitório, já que nêle existe cognição, embora parcial, com solução da lide. A falta de contradição do devedor, em razão do princípio dispositivo, opera a preclusão do mandado, outorgando-lhe eficácia vinculativa de sentença $\left({ }^{50}\right)$.

\section{Evolução no direito brasileiro}

15. Este amplo panorama histórico explica a presença, no direito brasileiro, dos procedimentos especiais dotados de mandado inicial imperativo.

Não conhecemos o mandado absoluto, sine clausula. Em tôdas as hipóteses legais permite-se a defesa do réu.

Nossas possessórias provêm das ações romanas de igual nome, da última fase, acrescidas do mandado medieval.

A executiva se origina da prática italiana.

A cominatória nasce, através dos "embargos à primeira" das

(47) CHIOVENDA, Instituições, 1.a ed. bras., § 31, p. 164; SOLMI, ob. cit., p. 207; MOACYR AMARAL SANTOS, ob. cit., p. 124.

(48) CHIOVENDA, op. cit., n.0 77, p. 361.

(49) CALAMANDREI, El Procedimiento Monitório, Buenos Aires, 1946, ps. 21, 24, 27 e 68.

(50) Ob. cit., ps. 49, 60, 62 e 64. 
Ordenações, dos mandados germânicos inspirados nos interditos romanos, para as obrigações de fazer e não-fazer, o mesmo ocorrendo, em regra, com as medidas cautelares.

Embora não contemos mais com a ação monitória obrigacional, equivalente no passado à nossa decendiária, podemos considerar, em sentido lato, monitórios todos aquêles procedimentos que autorizam - juiz a sentenciar de plano, em face da contumácia ou confissão do réu.

Na verdade, porém, faltam-nos disposições sistemáticas e genéricas a respeito do assunto.

Como vimos no início desta exposição, nossas leis processuais perdem-se num casuísmo impressionante, esquecidos autores e legislador não só da origem comum dos preceitos liminares, senão que, principalmente, da possibilidade de tratamento unitário e sistemático da matéria.

16. Ilustração significativa e nada lisonjeira dêste estado de despreparo, temo-la na penosíssima e lenta criação do mandado de segurança entre nós.

Perdemos, na verdade, vários decênios no teimoso equívoco de ampliar e violentar conceitos de direito material, porque dotados de proteção processual expedia, quando o que verdadeiramente dese¡ávamos era, tão só, o remédio processual sem o respectivo conteúdo, para proteger, sim, os direitos individuais in genere, contra atos ilegais ou abusivos da autoridade pública.

Tôda a luta de RUY BARBOSA pelo reconhecimento da posse dos direitos pessoais, tôda a admirável pregação de PEDRO LESSA, no Supremo Tribunal Federal, em prol da extensão do conceito de liberdade de locomoção, a forjar a chamada "doutrina brasileira do habeas corpus", padecem dêsse fundamental equívoco, um, violentando a noção de posse em razão do interdito liminar das ações possessórias, outro, ampliando desmesuradamenie aquêle conceito tendo em vista a proteção do habeas corpus, ambos desejosos, apenas, de um remédio expedito para tutela dos direitos subjetivos públicos do particular contra a autoridade.

Tínhamos a contemplar o ensinamento amplo dos interditos romanos do direito clássico, podíamo-nos inspirar na solução admirável dos mandata cum ou sine clausula do direito germânico medieval, ou dos notáveis writs anglo-americanos; contávamos, até, com a lição do amparo mexicano, a nosso alcance desde meados do século passado. 
Não há razão, portanto, para nos vangloriarmos da tardia adoção de nosso mandado de segurança.

Muito há, na verdade, que edificar para preencher as lacunas de nosso empirismo, se quisermos, efetivamente, usufruir um procedimento adequado às necessidades dos tempos modernos.

\section{Lição da história: a existência de dois sistemas processuais.}

17. A milenar lição da história revela, como vimos, a co-existência de dois sistemas processuais perfeitamente diferenciados, um, a iniciar-se com mandado liminar de autoridade, outro, a pressupor - equilíbrio e igualdade das partes no contraditório.

A incidência maior ou menor de qualquer dêsses sistemas em face do outro depende, contudo, de fatôres estranhos ao direito processual.

Já tivemos oportunidade de mostrar como o processo não passa, no fundo, de um produto da cultura e da civilização do meio onde atua $\left({ }^{51}\right)$. Num ambiente de individualismo jurídico, o rito processual se torna lento, pesado, longo no tempo. Na medida, porém, em que preponderem valores sociais, a tendência se inverte, em favor do procedimento sumário. O ideal haverá de residir, evidentemente, no justo equilíbrio destas tensões.

Vimos que o povo romano perdeu com o evolver dos séculos, talvez sob o influxo dos vagares do Oriente, e de novas concepções políticas e filosóficas, a noção publicística do interdito, como meio pronto, simples e eficaz de solução do litígio.

PONTES DE MIRANDA, em página de grande beleza, lembra que "os interditos, no fundo, serviam à vida, à vida tal como exsurgia, sem as peias das combinações conceptuais"' $\left({ }^{52}\right)$.

Mais tarde, no fim da Idade Média e na Renascença, a valorização política e social do homem e a necessidade econômica de acelerar-se o tráfico mercantil forçaram a redescoberta da fórmula interdital romana para atribuir-lhe objeto talvez mais amplo e diversificado, em função dos novos valores vigorantes.

Com avanços e recuos, a eterna antinomia entre o individual e o social no processo, aquêle a postular um ideal de justiça absoluta, com fórmulas e têrmos infindáveis, êsłe a exigir a eliminação

(51) Processo e Cultura, Rev. de Dir. Proc. Civil, 30 v., p. 74.

(52) Comentário ao C.P.C., 2.a ed., VI, p. 41. 
pronta e rápida do litígio, permanece a desafiar nossa argúcia na ânsia de descoberta do equilíbrio adequado.

Já se vê que os dois sistemas apontados representam, no fundo, a projeção dêsse dualismo axiológico que porfia no direito processual, como reflexo, aliás, do trágico conflito entre indivíduo e sociedade, que radica na própria natureza humana, eis que no processo se manifesta o sinal de nossa angústia.

18. Mas, considerando, agora, o assunto em outro plano, verifica-se que os dois sistemas processuais correspondem, também, a uma distinção teórica fundamental, que devemos ao gênio de CARNELUTTI, na célebre polêmica mantida com CALAMANDREl, a respeito da essência da jurisdição ${ }^{(53)}$.

Em resposta a uma das críticas mais contundentes quanto à posição lógica da lide como nota conceitual da jurisdição, lide que, segundo CALAMANDREI, não existiria na função executória jurisdicional do processo, pois que já resolvida pela sentença, CARNELUTTI mostra como a existência do contraditório não é essencial para caracterizar-se o conflito de interêsses. Exatamente o fato da execução constitui a prova mais eloquente do perdurar do conflito, não mais contraditado, é verdade, mas vivo, presente, enquanto não se satisfazer o direito.

Distingue, então, CARNELUTTI lide com controvérsia de lide sem controvérsia, ambas conduzindo a processos de natureza jurisdicional.

Ora, afigura-se-nos que os dois sistemas processuais entrevistos pela análise da história representam, na verdade, a comprovação existencial do acêrto desta distinção básica da teoria geral.

O procedimento comum ou ordinário pressupõe a existência de lide com controvérsia. Daí, a necessidade de assegurar-se ab-initio uma rígida posição de igualdade entre as partes no processo de cognição. Daí, o ônus do contraditória recair sôbre o autor, pois não se the presume, desde logo, a titularidade do direito. É bem possível que a razão assista ao réu. Daí, a audiência inicial de atos imperativos de autoridade.

Daí, a presença neutra e igualitária das audiências de instrução, sem compromisso com qualquer das partes.

Quando, porém, não houver razão de ser para esta presunção inicial de igualdade entre as partes, ou porque milite em favor do

(53) V. Rev. de Direito Processual italiana, vol. de 1928. 
demandante um título líquido e cerro, ou porque o interêsse público ou social exijam reconhecimento provisório, a priori, das razões dêste, não se justifica a manutenção de um modêlo processual previsto para outra finalidade.

Aqui, a presunção inicial, portanto, é a da existência de uma lide sem controvérsia. Nada impede, portanto, a expedição de mandado liminar, em favor da tutela requerida. Cumprido aquêle, de duas uma, ou o réu efetivamente não contesta e, nestas circunstâncias, nenhum sentido teria a audiência comum, podendo, assim, a cognição terminar imediatamente; ou opõe-se ao pedido, assumindo, então, o ônus da iniciativa do contraditório.

Não se lhe impede, pois, o exercício do direito de defesa, mas se goza da enorme vantagem, em têrmos de economia processual e rendimento do serviço forense, de eliminar-se o acúmulo da pauta de audiências com demandas totalmente inúteis, na prática tão numerosas, porque a revelia ou a confissão do réu tornam inane êste ato processual. Modêlo de contrassenso, a êste respeito, são os atuais dispositivos do Código quanto à ação executiva.

19. Estamos, portanto, em face de dois sistemas processuais, de duas modalidades igualmente válidas de fazer-se justiça, as quais resultam, como instrumento adequado e distinto, da natureza vária dos próprios valôres a serem tutelados pelo processo, e contam, por isto mesmo, a seu favor, com o testemunho da história.

Claro que o conteúdo material dêsses valores, que a oção de distribuí-los por um tipo ou outro de procedimento, representa decisão política, em função de contingências ideológicas, culturais, ou de imperativos sociais ou econômicos da época.

Oportunas, sem dúvida, se apresentam estas considerações no momento em que se cogita, com tanta propriedade, da reforma processual entre nós.

Vimos que, nos últimos tempos, a necessidade de acelerar-se o desenvolvimento social e econômico do País fêz com que leis especiais adotassem formas mais expeditas, embora atenuadas, de procedimento monitório de caráter executivo. Destacamos, especialmente, como causa dessa adoção, os imperativos decorrentes da reforma agrária, da execução dos planos habitacionais e da necessidade de apressar-se o giro no mercado de capitais, a benefício da produção e do comércio.

Acreditamos, contudo, que a disciplina processual do assunto 
reclame maior presença do processualista, e não apenas a do economista. Se assim fôra, não sofreriamos os graves inconvenientes do casuísmo dos ritos, impropriedade de nomenclatura e atropêlo de certos princípios indeclináveis.

Com efeito, se conhecido de nosso legislador extravagante o mecanismo do procedimento monitório europeu, onde o mandado liminar judicial incontestado vale automàticamente como título executivo, não haveria necessidade, por exemplo, de criarmos o grave precedente, de duvidosa constitucionalidade, na lei reguladora da alienação fiduciária, de uma autêntica execução direta pela parte, rompendo-se o princípio fundamental de que a execução coacta deve emanar sempre de título executório oriundo do Poder Judiciário.

Estas observações se tornam tanto mais pertinentes porquanto ainda não foi publicado pelo grande processualista que é ALFREDO BUZAID o capítulo destinado à disciplina dos processos especiais em seu Projeto.

Vimos que os procedimentos onde ocorre a inversão do contraditório podem comportar disciplina sistemática, com o que se evitaria a casuística, tão prejudicial a juízes e advogados, e tão pouco científica neste domínio.

A verdade é que nossos processos especiais tem sido vítimas da improvisação de legisladores, com criação desordenada e cheia de lacunas.

Porque, por exemplo, não estender-se o procedimento monitório (lato sensu) do mandado de segurança contra o ato ilegal do particular?

Por que motivo os atos do administrador de entidades públicas, hospitais, educandários, por exemplo, podem ser suspensos pela liminar da segurança, e atos idênticos, igualmente lesivos, de administradores dessas mesmas entidades, quando privadas, escapam aos efeitos da salutar medida, em virtude da absoluta carência, entre nós, de remédio processual expedito e adequado.

Aqui ficam, pois, estas sugestões em prol da adoção, no nôvo Código, de modelos sistemáticos de procedimento monitório, de forma a eliminar-se, em proveito da celeridade dos juízos e perfeição e harmonia no emprego, até ampliado, do remédio, o abundante e estéril casuísmo vigorante entre nós.

Podemos justamente orgulhar-nos de nossas criações no que concerne ao direito processual-constitucional. 
Urge, porém, quanto antes, que idêntico sentimento nos invada em relação ao direiio processual, êle mesmo, de tal modo que a anunciada reforma concilie os ideais de justiça eficaz com procedimento célere, para que nossos instrumentos de declaração e realização daquilo que é justo acompanhem, sem demora, os ventos de renovação e de progresso que sacodem, atualmente, êste imenso e admirável País. 